\title{
EXEMPLOS DE RECONSTITUIÇÕES DA VEGETAÇÃO E INFERÊNCIAS DE PALEOCLIMAS NO ESTADO DO RIO DE JANEIRO ATRAVÉS DA UTILIZAÇÃO DE BIOMINERALIZAÇÕES DE SÍLICA (FITÓLITOS) E ISÓTOPOS DE CARBONO
}

\section{Examples of vegetation reconstructions and paleoclimate in the state of Rio de Janeiro through the use of phytoliths indicators and carbon isotopes}

\author{
Heloisa Helena Gomes Coe \\ Professora Adjunta do Departamento de Geografia da Faculdade de Formação de Professores da UERJ \\ heloisacoe@yahoo.com \\ Jenifer Garcia Gomes \\ Mestranda em Dinâmica dos Oceanos e da Terra, Departamento de Geologia - UFF \\ jenifergg16@hotmail.com \\ Karina Ferreira Chueng \\ Graduanda do Departamento de Geografia na UERJ, RJ; \\ karinachueng@yahoo.com.br
}

Artigo recebido em 25/03/2013 e aceito para publicação em 31/07/2013

DOI: 10.12957/tamoios.2013.5363

RESUMO A compreensão de grande parte das formações vegetais primárias do Brasil necessita muitas vezes de estudos paleoambientais. Este trabalho apresenta dois estudos realizados em áreas do Estado do Rio de Janeiro, onde foram feitas reconstituições da vegetação e inferência de paleoclimas utilizando como indicadores os fitólitos e os isótopos de Carbono. Fitólitos são partículas de sílica que se formam como resultado da absorção pelas raízes das plantas de ácido silícico da solução do solo, precipitando-se depois, principalmente pela transpiração do vegetal, no interior ou entre as células vegetais. São importantes microfósseis, apresentando configurações típicas da vegetação de origem, pois a forma do fitólito recorda como um "molde" a célula vegetal em que foi formado. Os isótopos estáveis de Carbono são utilizados em estudos ambientais já que a composição isotópica varia de forma previsível conforme o elemento se move através dos diversos compartimentos de um ecossistema. Nas plantas, há um fracionamento constante dos isótopos do carbono para cada ciclo fotossintético. A razão entre os isótopos pode indicar que tipo de vegetal deu origem ao material estudado, complementando de maneira eficaz os resultados das análises fitolíticas.

Palavras-chave: Fitólitos; Isótopos de Carbono; Reconstituições da Vegetação; Mudanças Climáticas

ABSTRACT The comprehension of most of Brazilian primary vegetation often requires paleoenvironmental studies. This paper presents two studies in areas of the state of Rio de Janeiro where reconstructions of vegetation and paleoclimate inference were made, using phytoliths and isotopes of carbon as proxies. Phytoliths are particles of silica formed as a result of absorption of silicic acid in the soil solution by plant roots, precipitating later, mainly by transpiration of plants, within or between plant cells. They are important microfossils, with typical configurations of the vegetation source, since the shape of the phytolith remembers as a "model" the plant cell where it was formed. Carbon isotopes are used in environmental studies due to the fact that the isotopic composition varies in a predictable way as the element moves through the various compartments of an ecosystem. In plants, there is a constant fractionation for e cycle of photosynthesis. The ratio between the stable carbon isotopes can indicate which sort of plant originated the studied material, complementing efficiently the results of phytoliths analysis.

Key-words: Phytoliths; Carbon Isotopes; Vegetation Reconstitutions; Climate changes 


\section{INTRODUÇÃO}

A distribuição dos táxons, seja ela contínua, cosmopolita ou disjunta, é um problema ecológico ligado a fatores atuais e paleoambientais. A reconstituição da evolução da vegetação de uma região permite a inferência de mudanças paleoclimáticas.

Segundo Bigarella \& Lima (1982), a distribuição atual da vegetação é um ponto de partida para a interpretação do passado. Sem dúvida, estudos de Fitogeografia contribuíram para a compreensão do comportamento dinâmico e da história das formações vegetais. Estes estudos chamaram a atenção para o fato de que uma grande parte da vegetação primária em muitas áreas do Brasil não está de acordo com as condições climáticas e edáficas atuais.

Para explicar as discrepâncias entre a atual vegetação e o meio ambiente existem os estudos paleoambientais. A compreensão dos paleoambientes Quaternários requer uma abordagem interdisciplinar, envolvendo tanto a Biologia como as Geociências. O estudo destes ambientes é baseado numa variada metodologia, que inclui dados de Sedimentologia, Estratigrafia, Geomorfologia, Climatologia, Botânica, Zoologia, Biogeografia e Genética. Até o momento, ainda há grandes lacunas no nosso conhecimento sobre a evolução e diversidade atual da flora de algumas regiões brasileiras, razão pela qual acreditamos na relevância do incentivo aos estudos paleoambientais.

Reconstituições paleoambientais exigem sempre a utilização de um indicador (proxy), ou mesmo a combinação de vários deles (estudos multiproxies). Normalmente a palinologia é usada para reconstruções da vegetação. Entretanto, esse indicador, apesar de sua comprovada eficiência em muitos estudos, apresenta limitações quanto à disponibilidade de fontes de coleta de materiais e à identificação de gramíneas. Ao contrário, os fitólitos se preservam bem sob condições oxidantes, como nos solos. Por isso são muitas vezes, em áreas desprovidas de lagos ou turfeiras para coleta de testemunhos, os únicos indicadores disponíveis, além de serem excelentes para o estudo de gramíneas. A análise fitolítica pode ser empregada em substituição ou complementação à análise polínica. Ambas podem ser combinadas com análises isotópicas e outras.

Este artigo tem como objetivo apresentar alguns exemplos de aplicações das análises de fitólitos extraídos de perfis de solo combinadas a análises de isótopos de Carbono em duas áreas litorâneas do Estado do Rio de Janeiro: a Região de Cabo Frio/Búzios e a Bacia do rio São João.

\section{FUNDAMENTAÇÃO TEÓRICA}

\section{FITÓLITOS}

Fitólitos são partículas de opala $\left(\mathrm{SiO}_{2} \mathrm{nH}_{2} \mathrm{O}\right)$ microscópicas $(<60-100 \mu \mathrm{m})$ que se formam como resultado da absorção pelas raízes das plantas de ácido silícico [ $\mathrm{Si}(\mathrm{OH} 4)]$ da solução do solo, polimerizando-se e solidificando-se depois, principalmente pela transpiração do vegetal nos tecidos epidérmicos e vasculares das plantas (PIPERNO, 1988), sendo bem preservadas em solos e paleossolos. Estes corpos sólidos na planta terminam se incorporando ao solo com a senescência, queda e adição dos restos vegetais, onde permanecem por muito tempo, predominando na forma de pequenas partículas no tamanho areia fina (entre $0,06 \mathrm{~mm}$ e $0,2 \mathrm{~mm}$ ) e silte (entre 0,06 e $0,002 \mathrm{~mm}$ ). São bastante estáveis, já que resistem bem aos ataques químicos e biológicos em ambientes onde o material orgânico não se preserva bem, podendo tornar-se importantes microfósseis, uma vez que apresentam configurações típicas da vegetação de origem. A forma do fitólito recorda como um "molde" a célula vegetal em que foi formado.

As plantas absorvem a sílica através do sistema radicular, na forma de ácido monosilícico $\mathrm{Si}(\mathrm{OH}) 4$, quando o $\mathrm{pH}$ do solo se apresenta entre 2 e 9. Quando a pressão no interior da planta é 
negativa, ela absorve água (solução circulante do solo). Quanto maior a evapotranspiração (ET), maior a pressão negativa e maior a absorção. A sílica provém diretamente daquela dissolvida na solução do solo, em geral na forma de ácido silícico $\mathrm{Si}(\mathrm{OH} 4)$, o qual é bombeado pelas raízes e entra na composição da seiva bruta.

Várias são as aplicações das análises fitolíticas em estudos ambientais. No campo da Botânica e Paleoecologia servem para documentação e reconstrução da biodiversidade, através da verificação da similaridade dos fitólitos do solo com os da vegetação típica de formações preservadas e para reconstrução ambiental, já que fitólitos são indicadores confiáveis da vegetação natural e das plantas cultivadas. Por se preservarem bem sob condições oxidantes, como nos solos, os fitólitos são bons indicadores para estudos paleoambientais. Também são utilizados em estudos de Pedologia e Agronomia (por exemplo, na análise da distribuição de fitólitos em perfis de solo atuais e em horizontes enterrados), em Geoquímica Ambiental (sequestro de minerais pesados) e na Arqueologia.

Os fitólitos são produzidos em diversas partes da planta: 1) nas folhas de gramíneas ou de plantas lenhosas, principalmente na epiderme porque, por onde a água evapora. A concentração de ácido monosilícico é tão grande que a Si não circula, se precipita; 2) no tronco de árvores ou de arbustos, onde podem ser bastante interessantes do ponto de vista das informações (taxonomia e tipo de tecido); 3) nas raízes de gramíneas ou de plantas lenhosas, onde têm uma informação de tipo taxonômico ou ecológico muito baixa ou nula, com um morfotipo muito repetitivo e pouco característico. As células são muito uniformes, não havendo, portanto, grande diferenciação morfológica. Não há ET nas raízes, apenas a função de absorção, por onde entra o ácido silícico. A maior parte da silicificação é no interior da célula (citoplasma). Nos espaços intercelulares, os fitólitos são muito difíceis de serem identificados, ou apresentam grau de silicificação baixo (MADELLA, 2008).

Os tecidos onde se precipitam são principalmente a epiderme, o mesófilo das gramíneas e o xilema secundário das dicotiledôneas lenhosas (MOTOMURA et al., 2004). Nas células buliformes, que têm uma função muito específica nas gramíneas, sendo o motor para abrir e fechar durante as horas mais quentes do dia, diminuindo a ET, ocorre a formação dos fitólitos no interior das células.

Algumas famílias de plantas produzem fitólitos morfologicamente distintivos, como as dicotiledôneas lenhosas (globular granulate e blocky), as palmeiras (globular echinate), as ciperáceas (cone shape) e, principalmente, as Poaceae (gramíneas), que são as maiores produtoras e onde a distinção pode chegar ao nível de subfamília. A subfamília Panicoideae, característica de ambientes quentes e úmidos, produz principalmente fitólitos dos tipos bilobate, polylobate e cross. A sub-família Chloridoideae, característica de ambientes quentes e secos, produz principalmente fitólitos de tipo saddle, enquanto a sub-família Pooideae, característica de regiões temperadas, frias e altas elevações intertropicais, produz principalmente fitólitos do tipo rondel. Alguns fitólitos são característicos das Poaceae, sem que se possa distinguir de qual sub-família provém, como os que são produzidos nas células buliformes (bulliform cuneiform), nas células longas (elongate) ou nos pelos (acicular) (figura $1)$. 


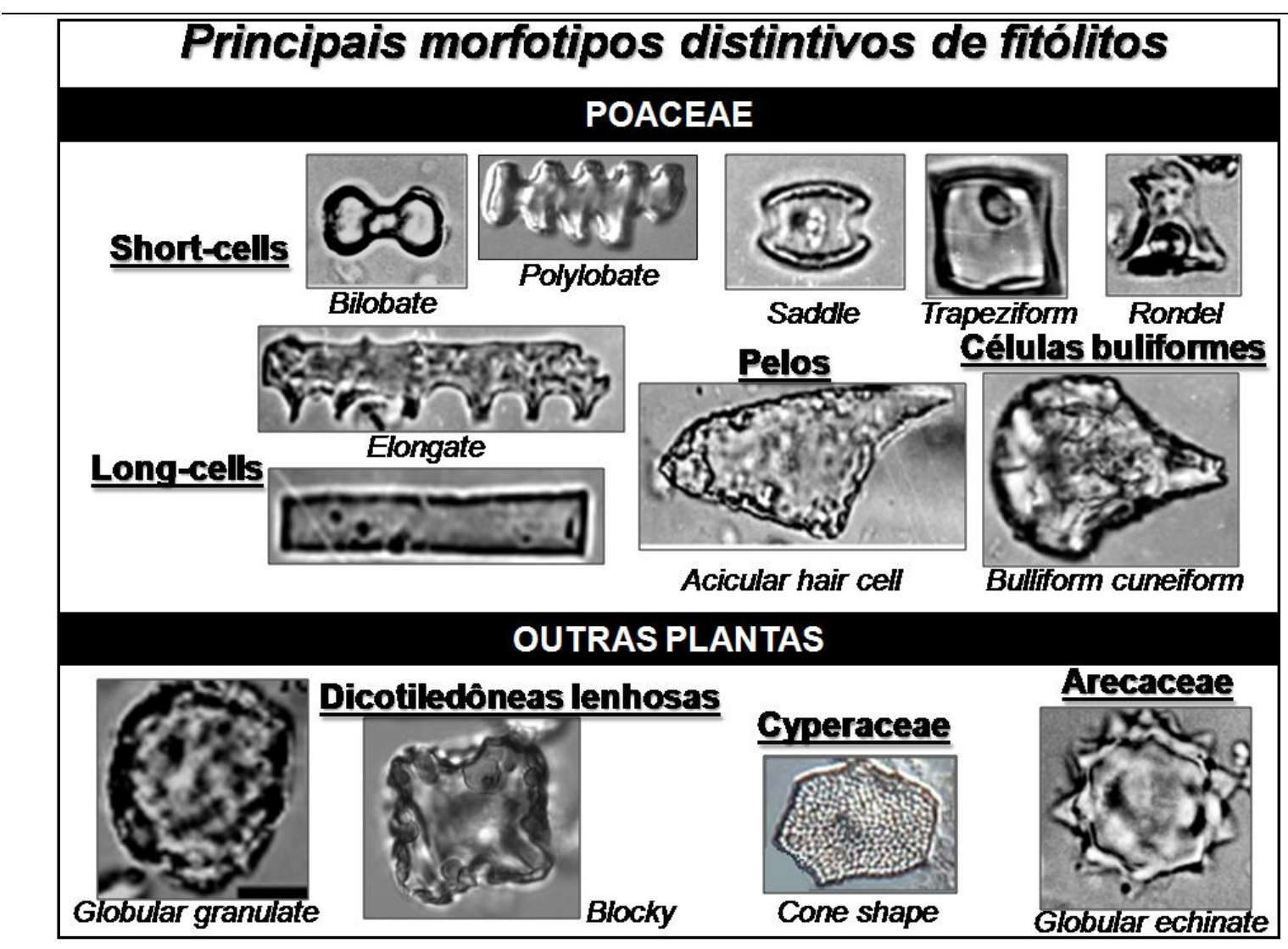

Figura 1: Principais morfotipos distintivos de fitólitos de Poaceae e outras plantas.

A produção de fitólitos é múltipla e redundante. Uma mesma planta pode produzir diferentes morfotipos. O mesmo morfotipo pode ser produzido em diferentes tecidos da planta e por diferentes plantas (redundância), que podem ou não ter uma relação taxonômica. Devido à multiplicidade e redundância da produção de fitólitos pelas plantas, às vezes é difícil atribuir valor taxonômico a um único fitólito. Entretanto, é possível identificar grupos de tipologias com valor taxonômico ao nível de tipo de vegetação. Estes grupos são chamados de assembleias fitolíticas. Uma assembleia fitolítica é constituída por um número estatisticamente válido de tipologias fitolíticas e representa a "produção média qualitativa e quantitativa" de fitólitos de uma vegetação em particular. Um único fitólito não permite, portanto, caracterizar um táxon, mas uma assembleia fitolítica permite caracterizar uma formação vegetal (BREMOND et al., 2005). Segundo o princípio da uniformidade, se um tipo de vegetação produz uma assembleia característica, ao encontrarmos essa assembleia no solo e/ou sedimento, podemos inferir que tipo de vegetação existia. Para fins de reconstrução ambiental, utilizase uma mescla de tudo o que pode fornecer uma informação geral. Assim, uma assembleia fitolítica é a soma dos fitólitos de assembleia geral com os fitólitos de assembleia com significado taxonômico e ainda, se houver, os esqueletos de fitólitos.

Para o estudo de adaptações ecológicas, com o pólen usam-se espécies modernas, das quais se conhecem os hábitos. Com fitólitos, nem sempre dispomos dessa linearidade. Não há uma listagem de plantas, e sim uma listagem de grupos (ex: floresta). Os estudos fitolíticos não procuram estabelecer que espécies constituíam essa floresta, mas se houve mudanças no tipo de cobertura vegetal, como por exemplo, de floresta para pradaria.

Estudam-se assembleias modernas e fósseis, calculam-se índices fitolíticos (relações de abundância em fitólitos), verificando-se se as sequências fitolíticas nos solos, resultantes dos processos de acumulação e/ou erosão, de translocação e de dissolução, mostram um aumento da idade média das partículas com a profundidade e podem ser interpretadas em termos paleoambientais (ALEXANDRE 
et al., 1997).

Os índices fitolíticos permitem inferir parâmetros de vegetação, tais como:

1) a densidade da cobertura arbórea (D/P), que mede a proporção de fitólitos de dicotiledôneas lenhosas (globular granulate) em relação aos fitólitos distintivos de Poaceae (bulliform cuneiform + short cells + acicular) (ALEXANDRE et al., 1997; BREMOND et al., 2005);

2) a densidade de palmeiras $(\mathrm{Pa} / \mathrm{P})$, onde se calcula a proporção de fitólitos de Arecaceae (globular echinate) em relação aos fitólitos distintivos de Poaceae (bulliform cuneiform + short cells + acicular) (COE, 2009);

3) o índice de aridez (Iph), que calcula a proporção de fitólitos de gramíneas C4, de ambientes quentes e áridos (saddle), ou C3, de ambientes quentes e úmidos (cross + bilobate) (TWISS, 1987; TWISS, 1992 apud BREMOND et al., 2005);

4) o índice climático (Ic), que indica a adaptação da formação vegetal a uma temperatura mínima e/ou à pressão parcial de Dióxido de Carbono (pCO2) forte (zonas de altitude) calculando-se a abundância relativa de gramíneas temperadas $\mathrm{C} 3$ (rondel + trapeziform polylobate + trapeziform short cell) em relação a gramíneas quentes C4 (saddle + cross + bilobate short cell) (TWISS, 1987; TWISS, 1992 apud BREMOND et al., 2005);

5) o índice de estresse hídrico (Bi), que calcula a proporção de fitólitos de células buliformes (bulliform cuneiform) em relação aos fitólitos distintivos de Poaceae (bulliform cuneiform + short cells + acicular) (BREMOND et al., 2005).

As sequências fitolíticas de solo podem registrar mudanças de vegetação em escala local ou regional. Como os fitólitos são liberados nos solos por humificação ou combustão da matéria orgânica, supõe-se frequentemente que uma grande proporção de fitólitos de solo seja originária da vegetação local. É principalmente o caso nas regiões equatoriais, onde serrapilheira e dossel diminuem o escoamento e o transporte eólico. Neste caso, a distribuição vertical dos tipos de fitólitos reflete as mudanças da composição da vegetação em escala local (RUNGE, 1999; BREMOND et al., 2005). Entretanto, os fitólitos podem, como outros minerais do solo, ser deslocados de seu sítio original pelo vento, água e animais, por longas distâncias (OSTERRIETH et al., 2009). Assim, por exemplo, sob condições climáticas áridas, com muito vento e quando a cobertura do solo é constituída por uma vegetação baixa e rarefeita, pode-se esperar um transporte eólico por uma longa distância. Neste caso, as assembleias registram mudanças regionais de vegetação (PIPERNO, 1988; BREMOND et al., 2005). Eventos extremos como fogo, enchentes, escavações podem também produzir grandes quantidades de fitólitos facilmente mobilizáveis (PIPERNO, 1988).

Calibrações entre assembleias fitolíticas, fisionomia das vegetações e limites climáticos mostram que os fitólitos são marcadores fiáveis e precisos das vegetações intertropicais e principalmente das diferentes formações herbáceas. A diversidade das formações herbáceas tropicais é o reflexo de uma diversidade climática, edáfica e antrópica que podem ser melhor compreendidas através das reconstituições fitolíticas (BREMOND et al., 2005). Seu estudo é útil para se compreender a evolução de uma vegetação e a relação desta com as condições bioclimáticas.

\section{ISÓTOPO DE CARBONO}

Os isótopos estáveis de Carbono, bem como os de outros elementos químicos, ocorrem naturalmente na atmosfera, hidrosfera, litosfera e biosfera (PESSENDA et al., 2005). Cada elemento tem um isótopo dominante "leve" (no caso do Carbono o ${ }^{12} \mathrm{C}$ ) e um ou mais isótopos "pesados" $\left({ }^{13} \mathrm{C}\right)$. Nas plantas, há a discriminação dos isótopos do carbono nos processos biológicos do ciclo da fotossíntese (BERRIER \& PROSSER, 1996). O uso de isótopos estáveis em estudos ambientais baseia-se no fato de que a composição isotópica varia de uma forma previsível, conforme o elemento 
se move através dos diversos compartimentos de um ecossistema. A relação entre o ${ }^{13} \mathrm{C}$ e $\mathrm{o}{ }^{12} \mathrm{C}$ praticamente não se altera, pois esses isótopos são estáveis. No entanto, a proporção ${ }^{13} \mathrm{C} /{ }^{12} \mathrm{C}$ não é idêntica em todos os materiais naturais, em função do chamado "fracionamento isotópico" (aproveitamento seletivo desses isótopos) que ocorre durante processos biológicos, físicos e químicos. Mas a diferença é pequena: nos materiais mais enriquecidos (com maior teor de ${ }^{13} \mathrm{C}$ ), a relação entre o ${ }^{13} \mathrm{C}$ e o ${ }^{12} \mathrm{C}$ é cerca de $3 \%$ (partes por 100 ) ou $30 \%$ o (partes por 1.000 ), maior que nos menos enriquecidos.

Em termos isotópicos, quando as plantas fazem fotossíntese, por razões de diferença de massa entre os isótopos, discriminam o mais pesado em favor do isótopo mais leve. Assim, as plantas tendem a ficar isotopicamente mais leves em relação à atmosfera. Este fracionamento é constante para as plantas de um mesmo ciclo fotossintético. A razão entre os isótopos estáveis de carbono pode indicar que tipo de vegetal deu origem ao material estudado, uma vez que seus valores são resultado de como o produtor primário assimilou o $\mathrm{CO}_{2}$, ou seja, a trajetória assimilatória utilizada e o isótopo preferencialmente assimilado (KILLOPS e KILLOPS, 2005).

A composição isotópica do Carbono é comumente expressa pela relação entre a concentração de átomos de ${ }^{13} \mathrm{C}$ sobre a concentração de átomos de ${ }^{12} \mathrm{C}$ presentes em uma amostra qualquer. Essa relação, muito pequena, é expressa em partes por mil (\%), e definida pela equação: $\delta^{13} \mathrm{C}=($ Ramostra - Rpadrão) / Rpadrão * 100 , onde Ramostra é a relação isotópica ${ }^{13} \mathrm{C} /{ }^{12} \mathrm{C}$ da amostra e Rpadrão é a relação isotópica ${ }^{13} \mathrm{C} /{ }^{12} \mathrm{C}$ do padrão (PESSENDA et al., 2005).

A variação isotópica do carbono (ou da relação ${ }^{13} \mathrm{C} /{ }^{12} \mathrm{C}$ ) é pequena em vegetais e na matéria orgânica do solo. Embora, durante o ciclo da fotossíntese o fracionamento isotópico seja pouco expressivo, ele permite classificar os vegetais terrestres em três grupos distintos: plantas C3, C4 e CAM. Os valores típicos de ${ }^{13} \mathrm{C}$ desses diferentes grupos fotossintéticos resultam de propriedades bioquímicas das enzimas de fixação primária do dióxido de carbono $\left(\mathrm{CO}_{2}\right)$ e da limitação à difusão desse gás nas folhas. Em plantas com fotossíntese $\mathrm{C} 3$, o $\mathrm{CO}_{2}$ é reduzido a fosfoglicerato (cuja molécula tem três átomos de carbono) por uma enzima que discrimina o ${ }^{13} \mathrm{CO}_{2}$. Isso resulta em valores relativamente mais baixos de ${ }^{13} \mathrm{C}$ nessas plantas. Nas plantas de fotossíntese $\mathrm{C} 4, \mathrm{o} \mathrm{CO}_{2}$ é reduzido a ácido aspártico ou málico (com quatro átomos de carbono nas moléculas) por uma enzima que não discrimina tanto o ${ }^{13} \mathrm{CO}_{2}$. Isso leva a valores de ${ }^{13} \mathrm{C}$ mais altos (maior teor de ${ }^{13} \mathrm{C}$ ) nas plantas $\mathrm{C} 4 \mathrm{do}$ que nas plantas C3 (FREITAS et al., 2002).

A análise $\delta^{13} \mathrm{C}$ da Matéria Orgânica do Solo (MOS) possibilita a identificação da formação vegetal que a originou como do tipo C3 (na maioria árvores) ou C4 (na maioria gramíneas). Diferentes mecanismos de assimilação do carbono permitem a distinção das fontes de $\mathrm{MO}$, através da avaliação dos sinais obtidos para a composição isotópica do carbono. De uma maneira geral, plantas C3, representadas pela maioria das plantas lenhosas (vegetação arbórea e arbustiva), assimilam $\mathrm{CO}_{2}$ através do ciclo de Calvin-Benson, apresentando valores $\delta^{13} \mathrm{C}$ que variam de -32 a $-22 \%$, com uma média de $-27 \%$, uma vez que assimilam preferencialmente moléculas do isótopo ${ }^{12} \mathrm{C}$. Gramíneas $\mathrm{C} 4$ utilizam o ciclo de Hatch-Slack e apresentam valores de $\delta^{13} \mathrm{C}$ que variam de -9 a $-17 \%$, com uma média de $-13 \%$. Existem ainda plantas CAM (Metabolismo Ácido das Crassuláceas), como as Crassulaceae, Euphorbiaceae, Orchidaceae, Bromeliaceae e Cactaceae, que apresentam valores de $\delta^{13} \mathrm{C}$ de -10 a $-28 \%$ (CAM facultativas), sendo que para algumas espécies CAM obrigatórias os valores isotópicos foram comparáveis aos de plantas C4 (BOUTTON, 1996). O fitoplâncton, que utiliza o carbonato dissolvido na água para realizar a fotossíntese, apresenta valores de $\delta^{13} \mathrm{C}$ próximos a -20\% (GLEIXNER, 2002, KILLOPS e KILLOPS, 2005) (Figura 2).

As plantas com ciclo fotossintético C4 (gramíneas e ciperáceas) dominam em regiões de savanas e campos e são mais resistentes a condições mais secas que as vegetações arbóreas de florestas tropicais (com ciclo fotossintético tipo C3). As plantas C4 apresentam maior produtividade que as plantas C3 em temperaturas mais altas e são típicas de vegetações mais abertas (preferem 
luminosidades mais intensas). Por isso, plantas C4 têm presença abundante em áreas tropicais e subtropicais e em muitos desertos. Já as plantas com ciclo CAM (orquidáceas e cactáceas) mostram maior diversidade e produtividade em ambientes secos, como desertos, ou em locais epifíticos (sobre outras plantas) em florestas tropicais (FREITAS et al., 2002).

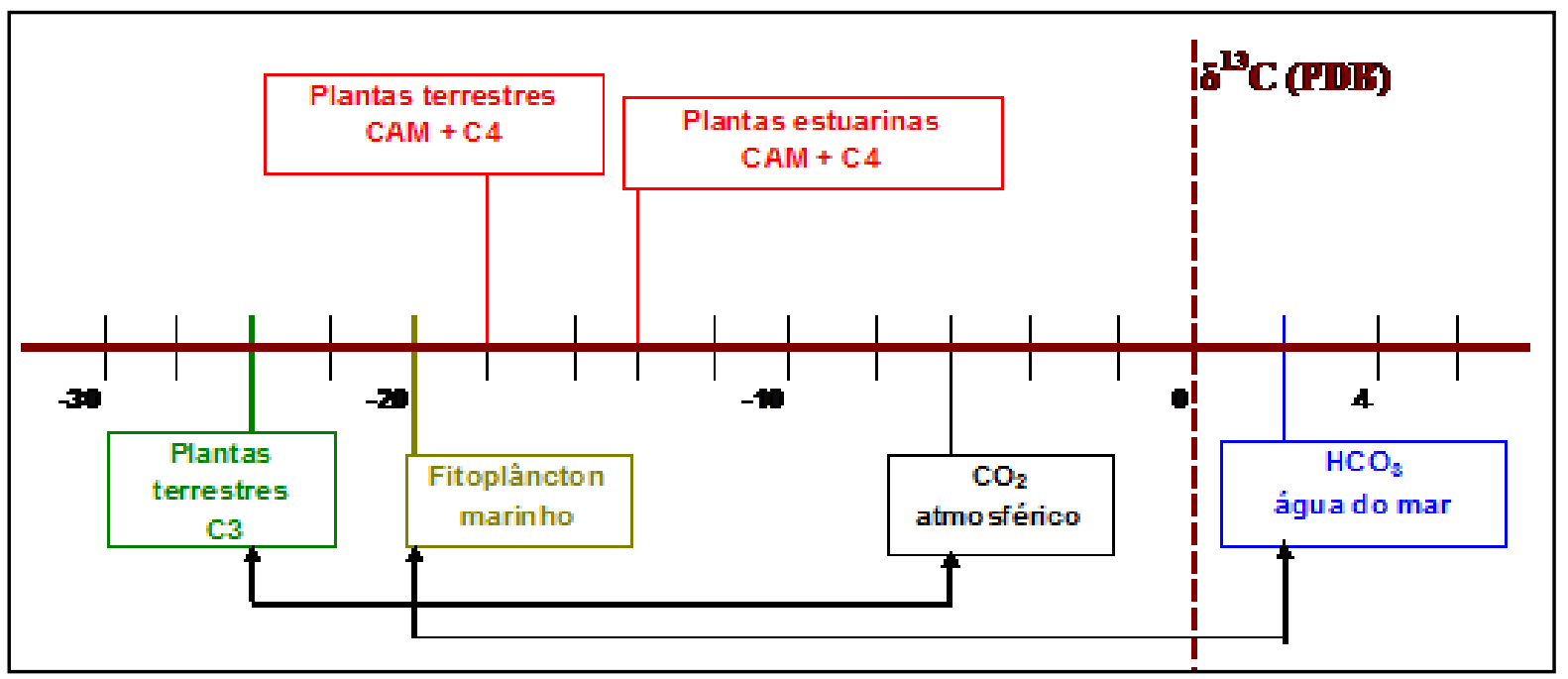

Figura 2: Fontes de $\mathrm{CO}_{2}$ e valores médios de $\delta^{13}$ C para diversos tipos de vegetais (Fonte: Coe, 2009, modificado de Libes, 1992).

Os valores de $\delta^{13} \mathrm{C}$ utilizados nas análises isotópicas se referem às fontes (plantas) e podem sofrer variações no solo (por exemplo, uma planta $-30 \%$ ao cair no solo pode transformar seu sinal em $-27 \%$, devido à decomposição do $\mathrm{N}$ e liberação do $\mathrm{CO}_{2}$ ). Na interpretação dos valores de $\delta^{13} \mathrm{C}$ da MOS, presume-se que as variações isotópicas menores que 3 a 4\% estão associadas ao fracionamento isotópico que ocorre durante a decomposição da matéria orgânica e às variações na composição isotópica do carbono do $\mathrm{CO}_{2}$ atmosférico (BOUTTON, 1996). Somente variações maiores que 3 a 4\%o são associadas às mudanças de comunidades de plantas (DESJARDINS et al., 1994).

$\mathrm{O}$ solo tende a ter uma combinação isotópica similar à cobertura vegetal sobrejacente. Entretanto, é importante pensar nas variabilidades na composição isotópica desses solos, pois provavelmente esta é um reflexo da variabilidade existente na composição isotópica da vegetação presente, mas também do fracionamento isotópico envolvido no processo de decomposição do material vegetal no solo. Estudos mostram que, durante a decomposição do tecido vegetal, ocorre um enriquecimento em torno de 1 a 2\% (MARTINELLI et al., 2009).

Nos casos de perfis de solo em que o enriquecimento isotópico com a profundidade é maior que 3 a 4\%, é provável que tenha havido uma mudança no tipo de vegetação durante a pedogênese desses perfis (MARTINELLI et al., 2009) . Exemplo disso é a substituição de uma floresta, predominantemente do tipo $\mathrm{C} 3$, por uma savana onde as espécies de gramíneas estabelecidas tenham sido predominantemente do tipo $\mathrm{C} 4$, como observado por Freitas et al. (2002) em estudos na Amazônia. A $3 \mathrm{~m}$ abaixo da superfície (datação de 17 mil anos AP), o valor de $\delta^{13} \mathrm{C}$ obtido indica que plantas C3 (floresta) eram dominantes em toda a região; entre 1,5 m (9 mil anos AP) e cerca de $70 \mathrm{~cm}$, os valores de $\delta^{13} \mathrm{C}$ tornaram-se em geral mais positivos, indicando maior presença de plantas $\mathrm{C} 4$ (savana) nessa camada; de $70 \mathrm{~cm}$ até a superfície, nos locais onde hoje há floresta, os valores ficaram gradualmente mais negativos, indicando um avanço da floresta (plantas C3) sobre a savana, e nos locais onde hoje existe savana, os valores também se tornaram mais negativos de $30 \mathrm{~cm}$ até a superfície, indicando um aumento da presença de plantas C3 nesses locais.

Por outro lado, em solos onde dominam campos naturais de gramíneas do tipo $\mathrm{C} 4$, a variação dos valores de $\delta^{13} \mathrm{C}$ com a profundidade do solo é distinta em relação a florestas, ocorrendo conforme 
a dinâmica da vegetação precedente. Geralmente há dois tipos de perfis, sendo: (1) aqueles onde por muito tempo a vegetação dominante é composta por gramíneas e; (2) aqueles onde atualmente dominam as gramíneas, mas antigamente dominava uma vegetação composta por plantas C3, ou uma mistura de plantas C3 e C4. (MARTINELLI et al., 2009)

Tipos de estudo que utilizam a composição isotópica do carbono para aferir mudanças passadas no tipo de vegetação são particularmente importantes em áreas que já sofreram mudanças climáticas pretéritas significantes. Em comunidades vegetais nas quais plantas C3 e C4 coexistem (ou coexistiram no passado), os valores de ${ }^{13} \mathrm{C}$ da MOS permitem reconstruir a produtividade relativa delas.

Determinando-se a provável paleovegetação, pode-se inferir paleoclimas. Por exemplo, as separações de vegetações de floresta existentes na Amazônia devem ter ocorrido através da expansão e da regressão dos campos (onde dominam as plantas com ciclo fotossintético C4) e florestas (plantas com ciclo C3). Essa dinâmica pode ser associada à ocorrência na região, no passado, de climas mais secos (que favorecem a expansão dos campos) e mais úmidos (que estimulam a expansão das florestas) (FREITAS et al., 2002).

\section{ÁREAS DE ESTUDO}

\section{REGIÃO DE CABO FRIO E ARMAÇÃO DOS BÚZIOS}

A área estudada ocupa aproximadamente $1.500 \mathrm{~km}^{2}$ e está localizada entre as coordenadas $22^{\circ} 30^{\prime}-23^{\circ} 00^{\prime} \mathrm{S}$ e $41^{\circ} 52^{\prime}-42^{\circ} 42^{\prime} \mathrm{W}$, com altitudes que variam desde o nível do mar até cerca de 300m, abrangendo os municípios de Arraial do Cabo, Armação dos Búzios, Cabo Frio, Iguaba, São Pedro da Aldeia e Araruama (figura 3).

A área apresenta peculiaridades climáticas, geológicas e ecológicas que condicionam diversas formações vegetais, com muitas espécies endêmicas e raras. De todos os fatores físicos, o clima parece ser o elemento que exerce maior influência sobre os ecossistemas da região. A marcante ação climática se faz visível na fisionomia seca que caracteriza as matas de Cabo Frio. Esta região apresenta um clima mais seco que o restante do litoral fluminense, relacionado, entre outros fatores, à presença de uma ressurgência costeira local. É considerada como um "enclave fitogeográfico", reduto de vegetação com fisionomia semelhante à da caatinga (AB SABER, 2003), dominada por florestas xeromórficas, com abundância de Cactaceae e Bromeliaceae e cercada por florestas úmidas da Mata Atlântica. 


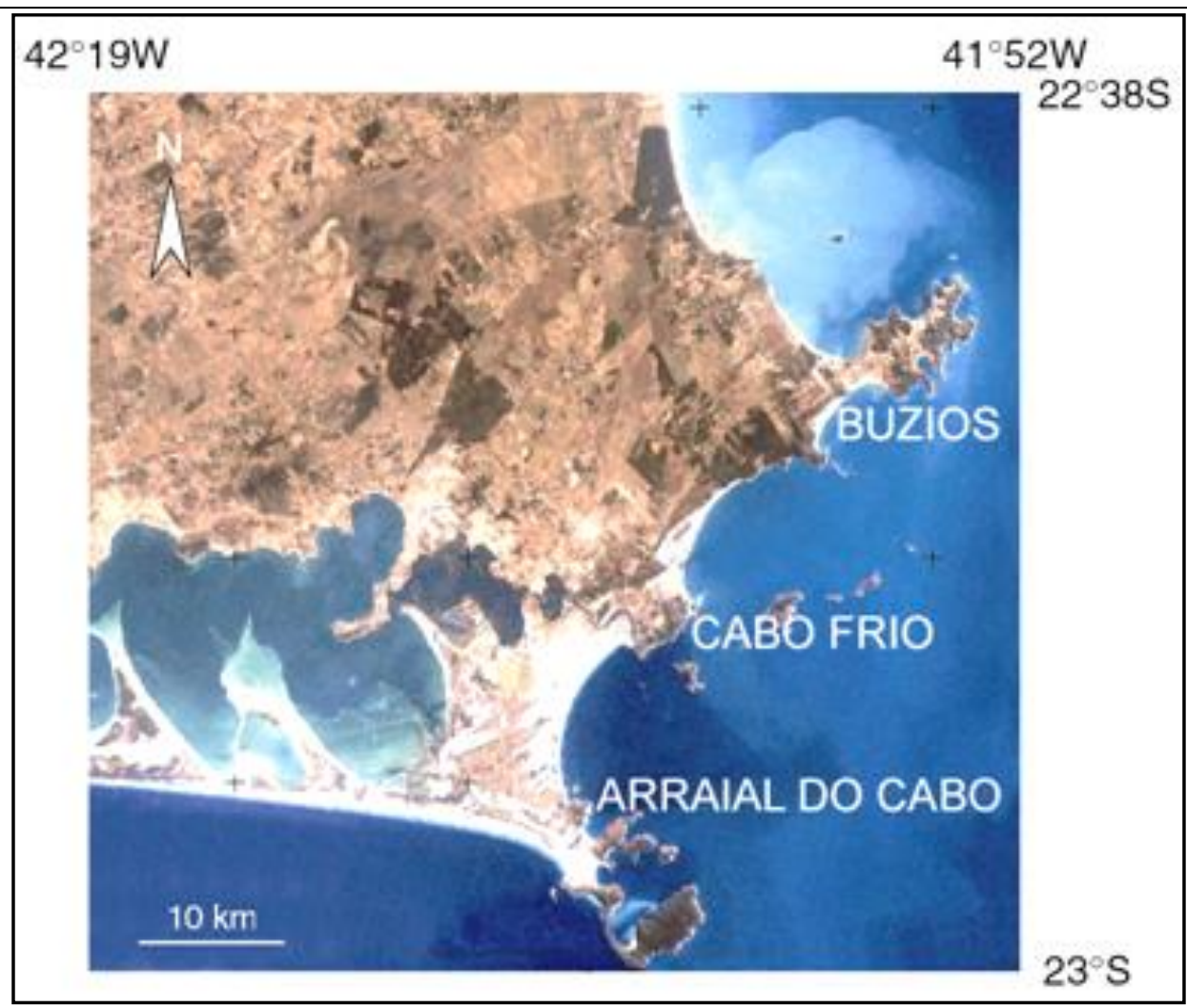

Figura 3: Localização da Região de Cabo Frio/Búzios (Fonte: Coe, 2009).

A região apresenta um complexo quadro geológico e geomorfológico, cuja litologia é composta principalmente por paragnaisses originados de depósitos marinhos pelíticos (SCHMITT, 2004), muito antigos e intemperizados, areias e materiais argilosos que formam espessos mantos de alteração, onde concreções ferruginosas e linhas de pedra podem ser encontradas. Esta parte do litoral fluminense, também conhecida como Região dos Lagos, é caracterizada por grandes lagoas e lagunas de água salgada ou salobra que foram isoladas do oceano por longos pontais distanciados do litoral, em grande parte, modeladas pelas variações do nível relativo do mar durante o Quaternário.

Os solos na região são pouco desenvolvidos, normalmente rasos, com características morfológicas, químicas e mineralógicas que sugerem um regime pedogenético particular (CAMARGO, 1979; MONIZ et al., 1990). Apresentam considerável variabilidade vertical e horizontal, sendo fortemente influenciados por fatores climáticos e topográficos. Os solos sob caatinga hipoxerófila constituem tanto o substrato fundamental ao ambiente sui generis, quanto a possibilidade de representarem pedoambientes outrora mais amplos e hoje isolados, mantidos graça às peculiaridades morfoclimáticas regionais (IBRAIMO et al., 2004).

\section{BACIA DO RIO SÃO JOÃO}

A bacia do Rio São João abrange os municípios de Araruama, Armação dos Búzios, Arraial do Cabo, Cabo Frio, Cachoeiras de Macacu, Casimiro de Abreu, Iguaba Grande, Rio Bonito, Rio das Ostras, São Pedro da Aldeia, Saquarema e Silva Jardim (figura 4). 


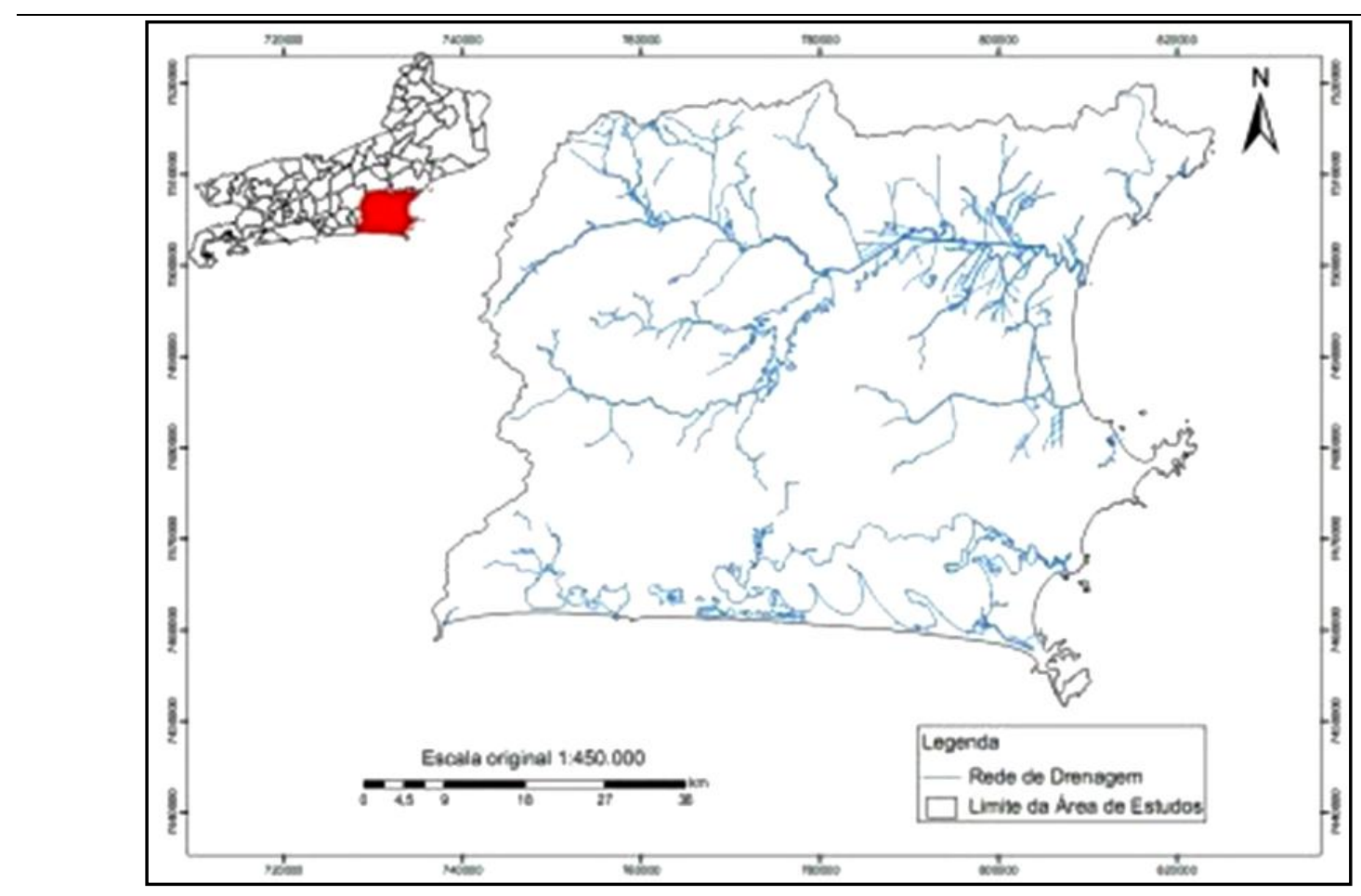

Figura 4: Localização da Bacia do São João (Modificado de DRM, 2008).

O clima é tropical com aumento das precipitações mensais no verão. As áreas setentrionais e mais elevadas da bacia apresentam maiores intensidades e frequências mensais e totais diárias que as áreas centrais e a leste. A bacia do São João se divide em três compartimentos geomorfológicos: áreas escarpadas, áreas de colinas e áreas de planície. As Escarpas Serranas são constituídas por relevo montanhoso, com vertentes retilíneas a côncavas. Na transição entre as serras escarpadas e a planície existe um compartimento de Colinas Isoladas, formas de relevo residuais, com vertentes convexas e topos arredondados ou alongados, com sedimentação de colúvios. Na área de planície podem-se distinguir Planícies Fluviais, Planícies Flúvio-Lagunares e Planícies Flúvio-Marinhas. As mais expressivas se localizam ao longo dos cursos médio e alto dos rios São João, Aldeia Velha e Bacaxá. (DRM-RJ, 2008).

\section{MATERIAIS E MÉTODOS}

Em ambos os exemplos de estudos apresentados foram realizadas as seguintes atividades:

1) Trabalhos de campo para coleta de amostras de solo, sedimentos e plantas para a realização de análises isotópicas e datação por ${ }^{14} \mathrm{C}$ AMS;

2) Análises granulométricas do material coletado;

3) Análises elementares e isotópicas dos solos e plantas: realizadas pelo Laboratório de Ecologia Isotópica do CENA/USP, através de um analisador elementar Carlo Erba modelo EA 1110, acoplado a um espectrômetro de massa, com um limite de detecção de $0,03 \%$;

4) Análises fitolíticas: os fitólitos foram extraídos, a partir de $20 \mathrm{~g}$ de solo seco, da fração 2 a $50 \mu \mathrm{m}$, após a dissolução dos carbonatos, a oxidação total da matéria orgânica, remoção dos óxidos de ferro, separação granulométrica e separação densimétrica $(2,35)$. Em seguida é feita a identificação e contagem das assembleias de fitólitos presentes em cada amostra em microscópio óptico com aumento de 600x. São contados pelo menos 200 fitólitos de diâmetro superior a $5 \mu \mathrm{m}$ e com significado taxonômico (classificados). São também contados os fitólitos sem significância taxonômica (não- 
classificados) devido a sua forma original ou subsequente dissolução ou fragmentação. As assembleias são apresentadas como porcentagens do total de fitólitos classificados. Segue-se a classificação de Twiss (1992), aumentada por Mulholand (1989), Fredlund \& Tiezen (1994), Alexandre et al. (1997), Barboni et al. (1999) e Runge (1999), de acordo com o ICPN (International Code for Phytolith Nomenclature 1.0), 2005. Após a contagem, são calculados os índices fitolíticos D/P, Pa/P, Bi, e Iph; 5) As datações por ${ }^{14} \mathrm{C}$ AMS da Matéria Orgânica do Solo (MOS) das amostras da região de Cabo Frio foram feitas na Universidade de Irvine, na Califórnia. As demais estão sendo realizadas nos laboratórios do Instituto de Física da Universidade Federal Fluminense.

\section{RESULTADOS E DISCUSSÕES}

\section{REGIÃO DE CABO FRIO/BÚZIOS}

O estudo teve como objetivo auxiliar na reconstituição paleoambiental da região, na qual pesquisas vinham sendo feitas através de análises de testemunhos oceânicos e lagunares, existindo ainda grandes lacunas na parte continental, devido à falta de indicadores de vegetação que se preservem bem em ambiente oxidante, já que a região carece de lagos adequados à coleta de testemunhos para, por exemplo, análises polínicas.

Foram analisadas amostras dos diferentes horizontes de quatro perfis de solo sob vegetação xeromórfica, além de horizontes superficiais de quatro tipos atuais de cobertura vegetal na região, que serviram como assembleias modernas de referência, a saber, mata seca com elementos de restinga; floresta úmida; caatinga hipoxerófila e brejo (figura 5).

Os principais tipos de fitólitos encontrados foram de gramíneas, sobretudo os que se formam em células maiores como o bulliform cuneiform, o elongate e o acicular; dentre os que se formam nas células curtas (short cells), o predomínio foi de saddle, produzido pelas Chloridoideae, adaptadas a ambientes quentes e secos, além de alguns bilobate e cross, produzidos pelas Panicoideae. Também foram encontrados fitólitos produzidos pelas dicotiledôneas lenhosas (globular granulate e blocky) e pelas palmeiras (globular echinate) (figura 6). 

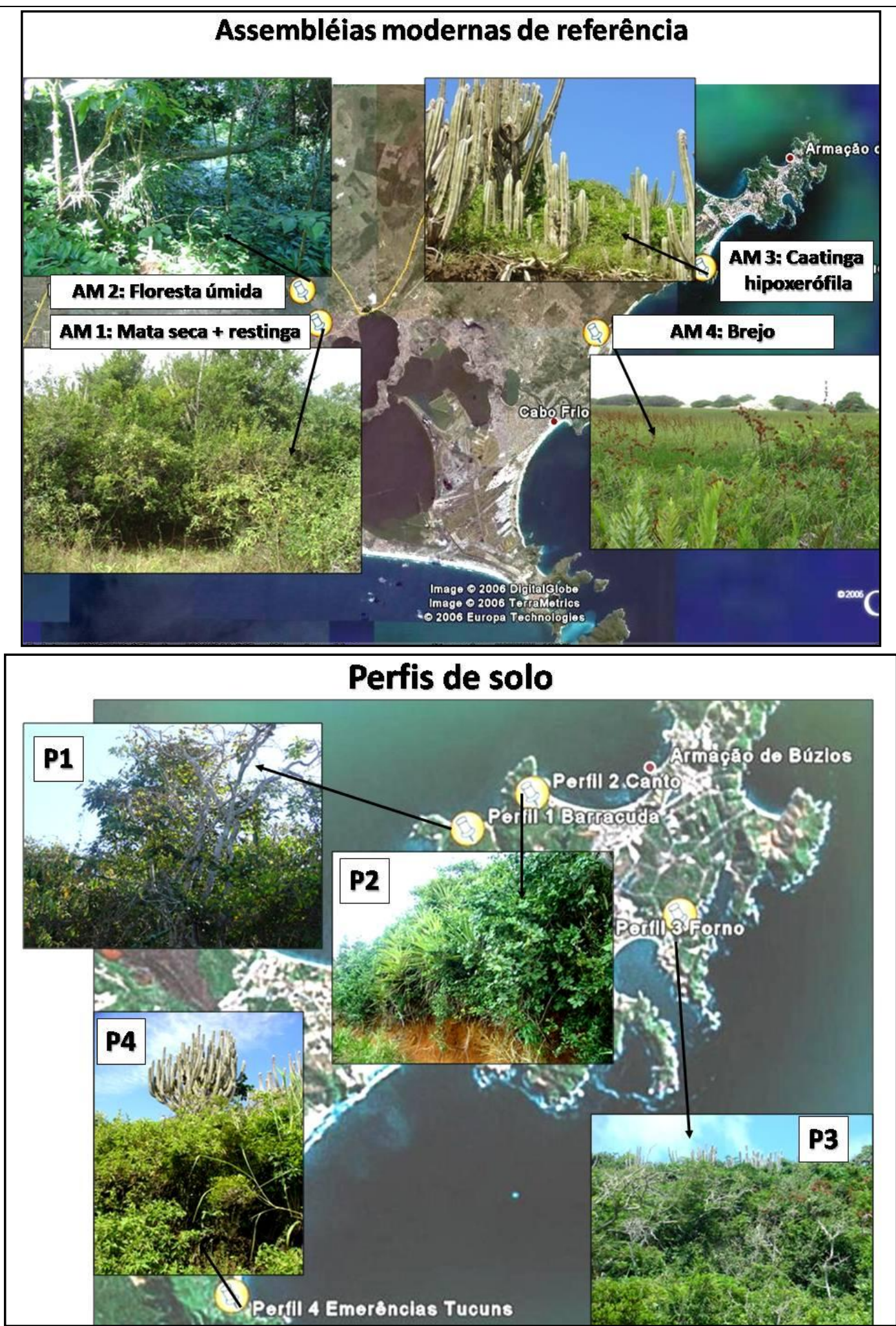

Figura 5: Localização dos pontos amostrados na Região de Cabo Frio. 


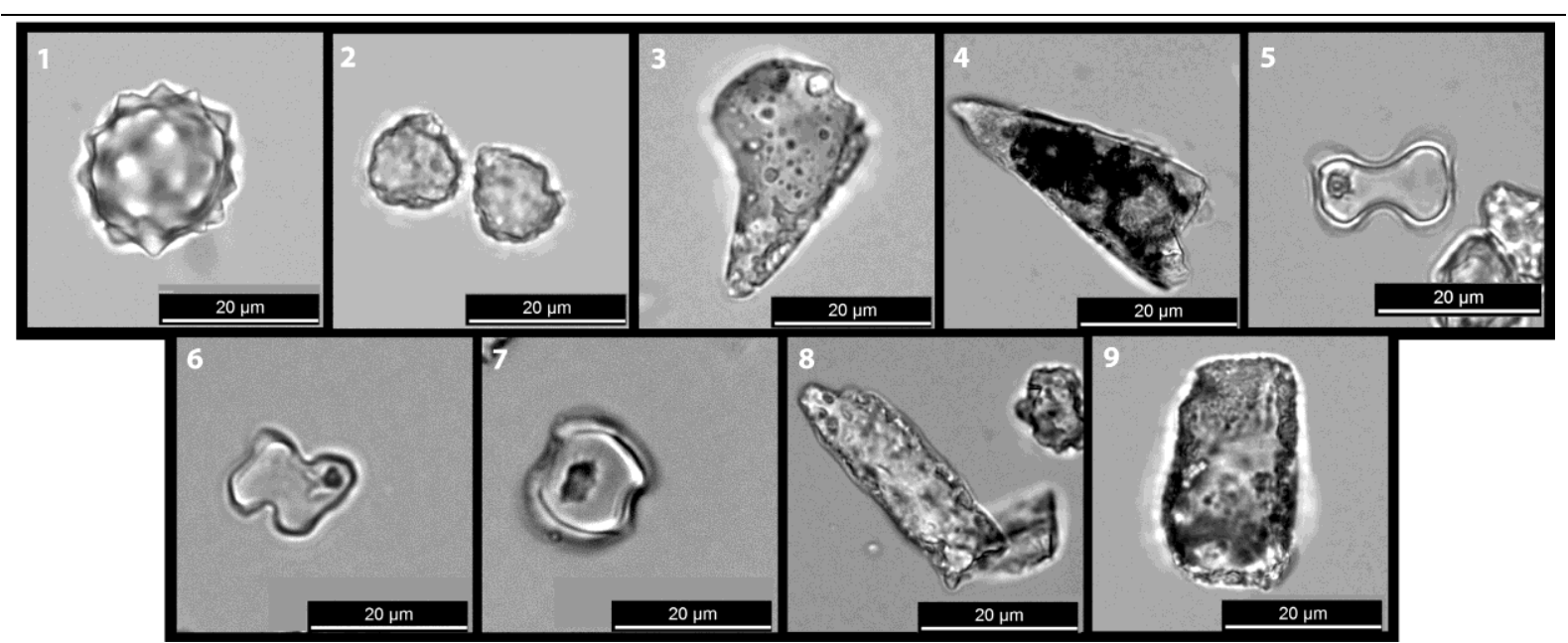

Figura 6: Principais tipos distintivos de fitólitos das amostras da Região de Cabo Frio: 1) globular echinate; 2) globular granulate; 3) bulliform cuneiform; 4) acicular;

5) bilobate; 6) cross; 7) saddle; 8) elongate; 9) blocky

(Fotos: Coe e Alexandre, 2011).

Para os perfis 1,2 e 3 foram calculados índices fitolíticos indicadores da densidade da cobertura arbórea (D/P) (figura 7a,b, 7c) e para o perfil 4 foi calculado o índice Pa/P (figura 7d).

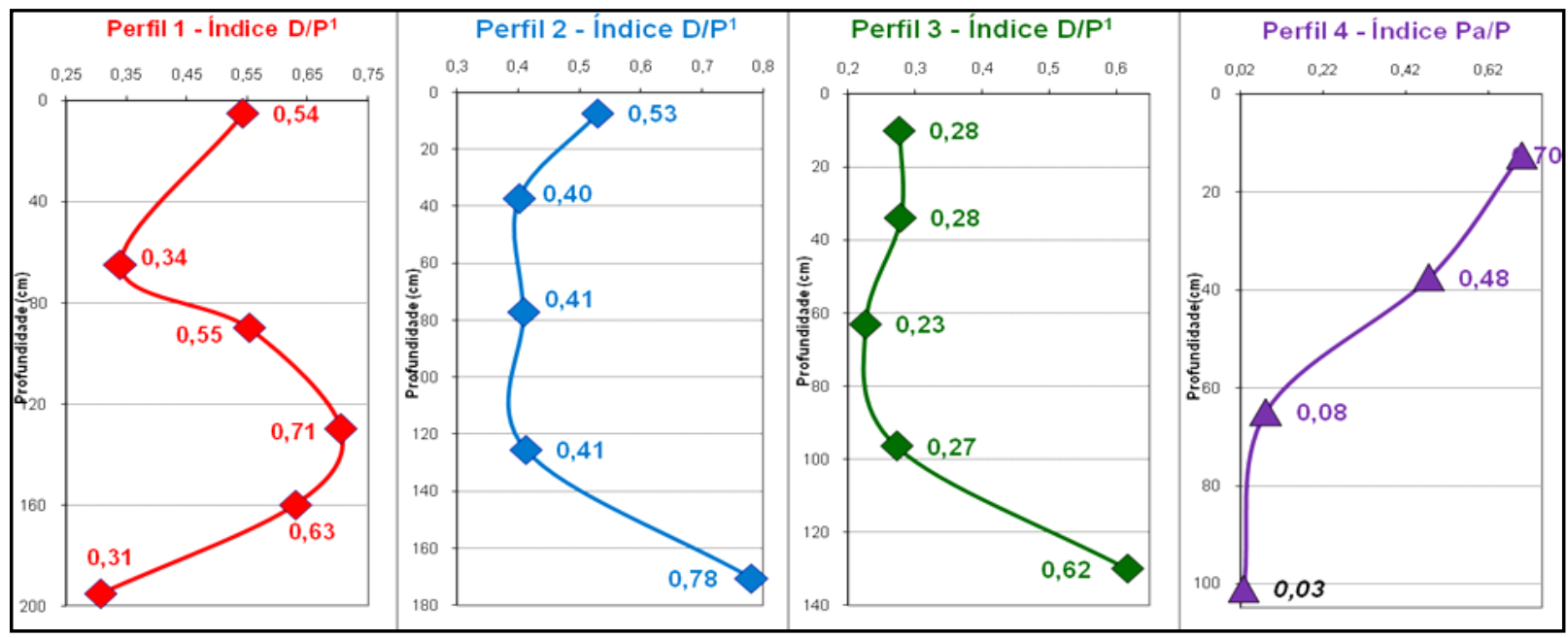

Figura 7: Índice D/P: a) Perfil 1; b) Perfil 2; c) Perfil 3; d) Índice Pa/P Perfil 4 (fonte: Coe, 2009).

Para o Perfil 1, o índice D/P varia entre 0,3 e 0,7, valores característicos de formações de savana, com variações ao longo do perfil. No horizonte mais profundo, datado em 13.000 anos cal AP, o valor é mínimo, aumentando em seguida para valores superiores ao atual, diminuindo em seguida para um valor similar ao atual, atingindo a $60 \mathrm{~cm}$ de profundidade valor similar ao mais profundo, para em seguida e em superfície, atingir um valor médio. Embora a cobertura vegetal da região nunca tenha atingido uma grande densidade arbórea, ao longo dos últimos 13.000 anos já foi inferior e superior a atual, indicando variações no clima.

Para o Perfil 2, o índice varia entre 0,4 e 0,8, valores característicos de formações de savana, com pouca variação ao longo do perfil, com exceção do horizonte mais profundo, datado em 6.210 anos cal AP, e que apresentou a maior densidade de cobertura arbórea. 
Para o Perfil 3, o índice D/P varia entre 0,2 e 0,6, valores característicos de formações de savana aberta, sem apresentar variações ao longo do perfil, com exceção do horizonte mais profundo, datado de 7.425 anos cal AP, e que apresentou a maior densidade de cobertura arbórea.

Para o perfil 4 o índice D/P não foi significativo. Entretanto, neste perfil foi registrada abundância de palmeiras (figura 7d), apesar de hoje praticamente as mesmas não são mais encontradas no local. Os fitólitos parecem registrar a presença de uma vegetação cuja diminuição tem provavelmente origem antrópica, sendo então possível relacionar os resultados com o histórico de ocupação e degradação da região.

Para os perfis de solo, o conjunto geral de resultados de $\delta^{13} \mathrm{C} \%$ (figura 8), com poucas exceções, não apresentou grandes variações nos sinais isotópicos em profundidade. Excluindo-se os horizontes $\mathrm{P} 1 \mathrm{Ab}, \mathrm{P} 3 \mathrm{Ab}$ e $\mathrm{P} 3 \mathrm{Bb}$, todos os demais apresentaram valores com sinais de plantas $\mathrm{C} 3 \mathrm{ou}$ CAM, embora não muito empobrecidos (entre -26 e -22\%o), o que pode representar uma mistura de sinais de plantas C3, C4 e CAM, com predomínio de plantas C3. Em todos os perfis verifica-se uma tendência de empobrecimento de ${ }^{13} \mathrm{C}$ (valores mais negativos) da MOS da base para o topo. O perfil mais empobrecido foi o P2 (de -26 a -23,5\%) e o mais enriquecido foi o P1 (de -23,3 a -20,8\%). O perfil que apresentou variações mais significativas (acima de 3\%) foi o P3.

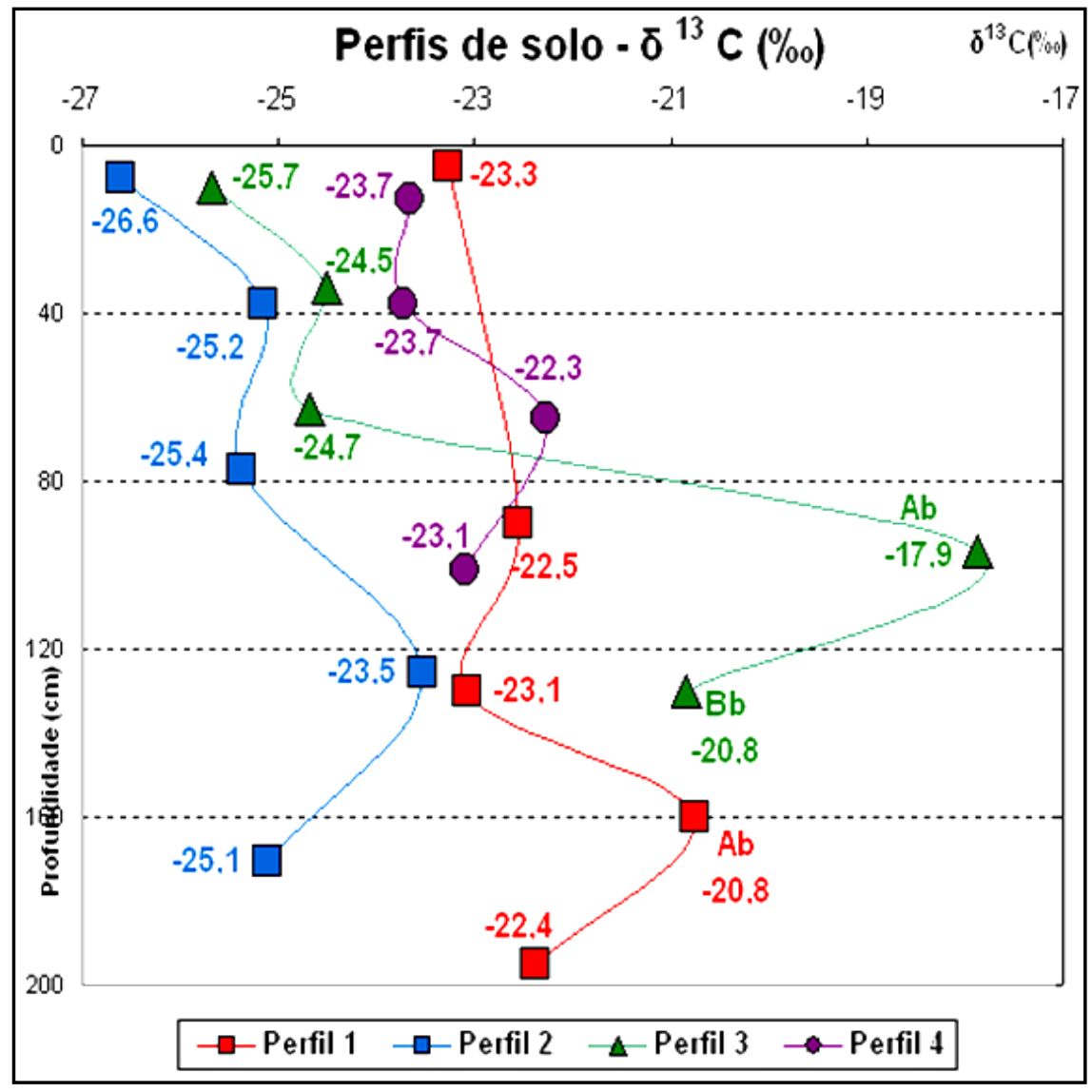

Figura 8: Valores $\delta^{13}$ C (\%o) dos perfis de solo (fonte: Coe, 2009).

Os resultados fitolíticos foram comparados com os isotópicos $\delta^{13} \mathrm{C}$ e dos fenóis de ligninas (figura 9). 


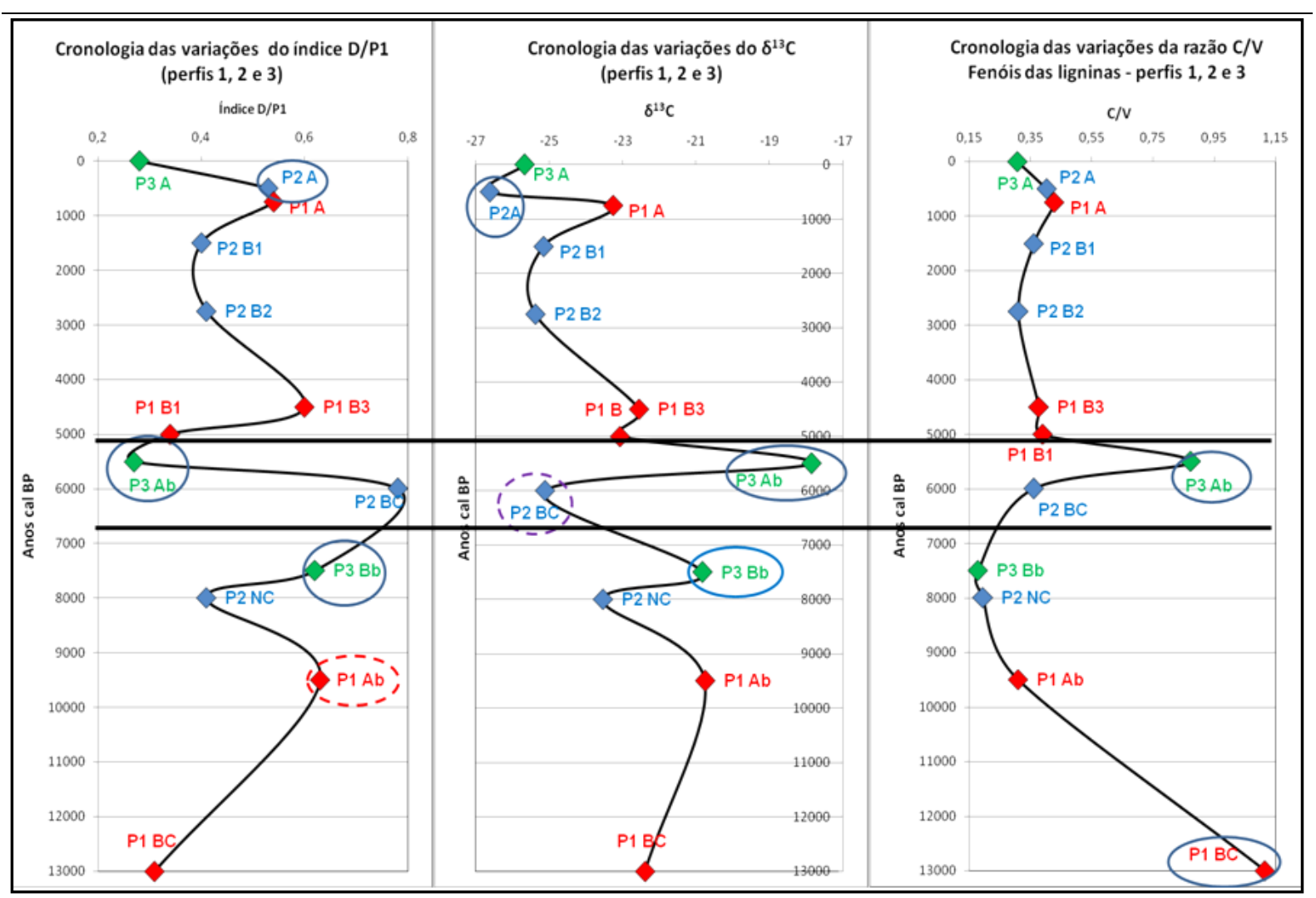

Figura 9: Cronologia das variações dos índices $D / P, \delta^{13} C$ e $C / V$ dos perfis 1, 2 e 3, Búzios. Destaque para o período mais seco ocorrido entre 5500 e 5000 anos AP (fonte: Coe, 2009).

Se interpretarmos os períodos de maior densidade arbórea como mais úmidos e os de menor densidade como mais secos, podemos inferir que há 13.000 anos cal AP, final do Pleistoceno, o clima na região de Búzios/Cabo Frio era mais seco que o atual. Podemos observar grandes tendências (períodos de maior ou menor densidade arbórea) na evolução da vegetação da região de Búzios/Cabo Frio. A partir de 13ka cal AP não houve grandes mudanças no tipo de cobertura vegetal (floresta xeromórfica). De $13 \mathrm{ka}$ cal AP a cerca de $6 \mathrm{ka}$ cal AP, a tendência é de aumento da cobertura arbórea. Esta tendência corrobora com registros de ressurgência mais fracas (Andrade, 2008; Oliveira, 2008). De 6ka cal AP a 1,5ka cal AP, a tendência é a diminuição da cobertura arbórea, correlacionada a registros de ressurgência e episódios El Niño mais intensos (ANDRADE, 2008; OLIVEIRA, 2008). Dentro dessa fase, o período de menor densidade arbórea foi entre 5,5 e 5ka cal AP, quando, além dos menores índices $\mathrm{D} / \mathrm{P}$, também se verificou um enriquecimento do $\delta^{13} \mathrm{C}$ e um aumento da razão entre os fenóis $\mathrm{C} / \mathrm{V}$ das ligninas, característicos de uma abertura da vegetação. A partir de 1,5ka cal AP, o sinal fitolítico já não registra variações e os estudos sobre a ressurgência apontam um período de grande variabilidade da mesma.

As variações no nível do mar, registradas a nível regional (costa leste do Brasil), não parecem ter relações diretas com as mudanças na cobertura vegetal de Cabo Frio. Estas mudanças parecem ser mais influenciadas por variações na intensidade da ressurgência, de âmbito local. Parece haver boa concordância entre os resultados dos estudos sobre a ressurgência e o sinal fitolítico, apesar de algumas diferenças devidas, sobretudo, à escala de tempo das mudanças que podem ser registradas pelos primeiros e a resposta da vegetação (registrada pela análise fitolítica) a essas mudanças. As análises fitolíticas registram mudanças na vegetação que podem ser a nível local, sem necessariamente estarem ligadas a grandes mudanças climáticas em escala mais regional. 


\section{BACIA DO RIO SÃO JOÃO}

O segundo exemplo apresentado é parte de um projeto de estudo de topossequências de solos e sua relação com a geomorfologia, geologia, cobertura vegetal, uso do solo, precipitação e qualidade das águas na bacia do rio São João, visando compreender a gênese desses solos e identificar mudanças ambientais na área, como subsídio no planejamento ambiental da bacia. Na bacia do rio São João, foram analisadas amostras de quatro perfis de solo (GOMES, 2012): um glei, um neossolo flúvico, um argissolo e um planossolo, além de sete amostras superficiais de solo subjacentes aos principais tipos de cobertura vegetal atualmente existentes na bacia (manguezais, pastagens, florestas e brejo), que serviram como assembleias modernas de referência (figura 10).

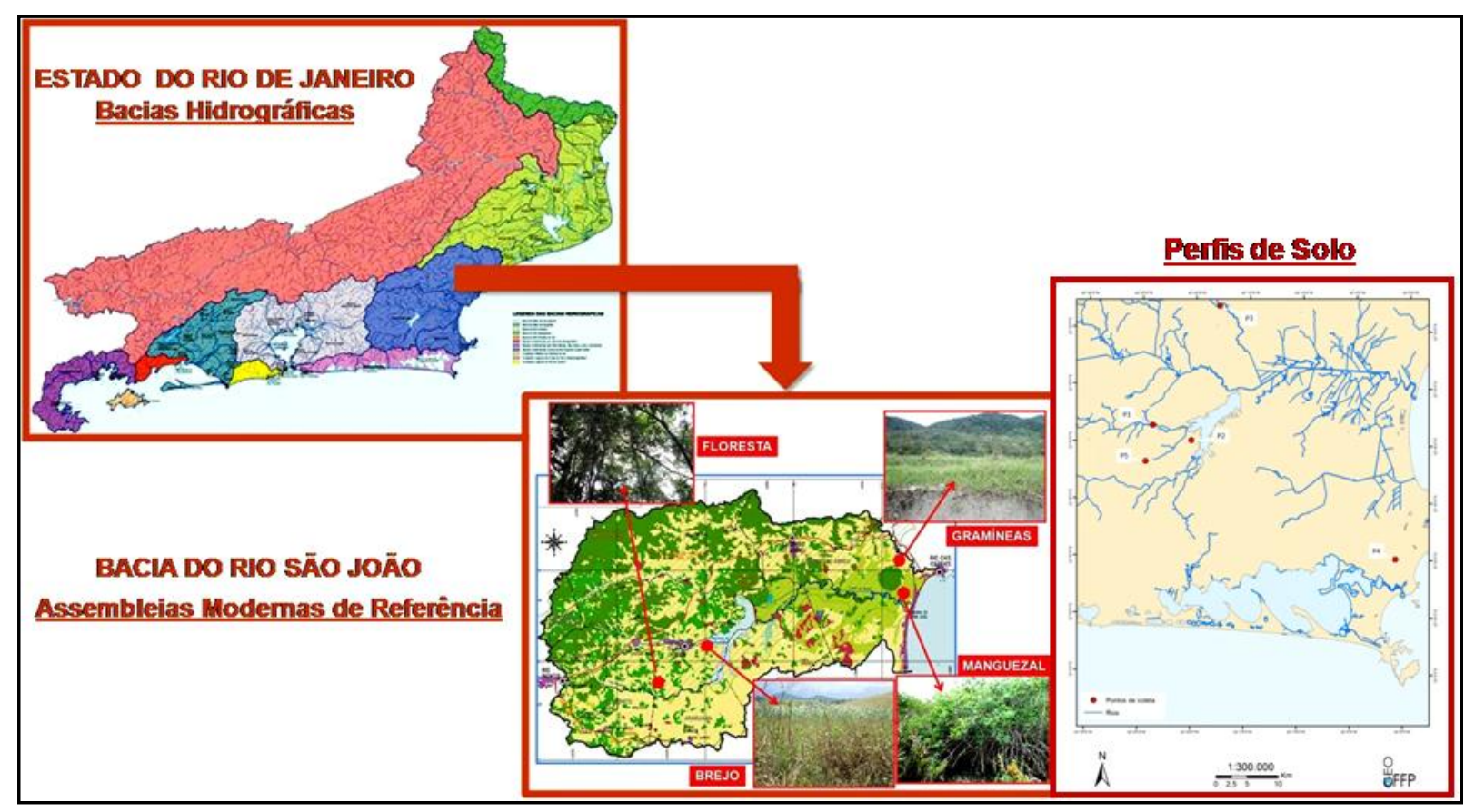

Figura 10: Localização dos pontos amostrados na Bacia do Rio São João

(Fonte: Modificado de Gomes, 2012).

Observações microscópicas permitiram identificar assembleias fitolíticas em todos os horizontes desses solos, com variações na quantidade de fitólitos e nos seus tipos de acordo com a origem do material onde ocorreu a pedogênese. Solos com material de origem aluvial apresentaram fitólitos muito misturados e em quantidade semelhante em todos os horizontes. No solo glei, foram observados como fitólitos predominantes os de gramíneas (bulliform, acicular e elongate) e de palmeiras (globular echinate). No neossolo flúvico predominaram os fitólitos de dicotiledôneas lenhosas (globular granulate) e entre os de gramíneas os tipos bilobate e bulliform. Entre os solos desenvolvidos a partir do material eluvial identificou-se: no argissolo o predomínio de determinados tipos como o bulliform e o globular granulate e o teor em fitólitos diminui com a profundidade, segundo o padrão normal de distribuição; no planossolo, os fitólitos são carreados dos horizontes orgânico e eluvial e se concentram no horizonte textural, apresentando predominantemente os tipos bulliform e elongate (Figura 11). 


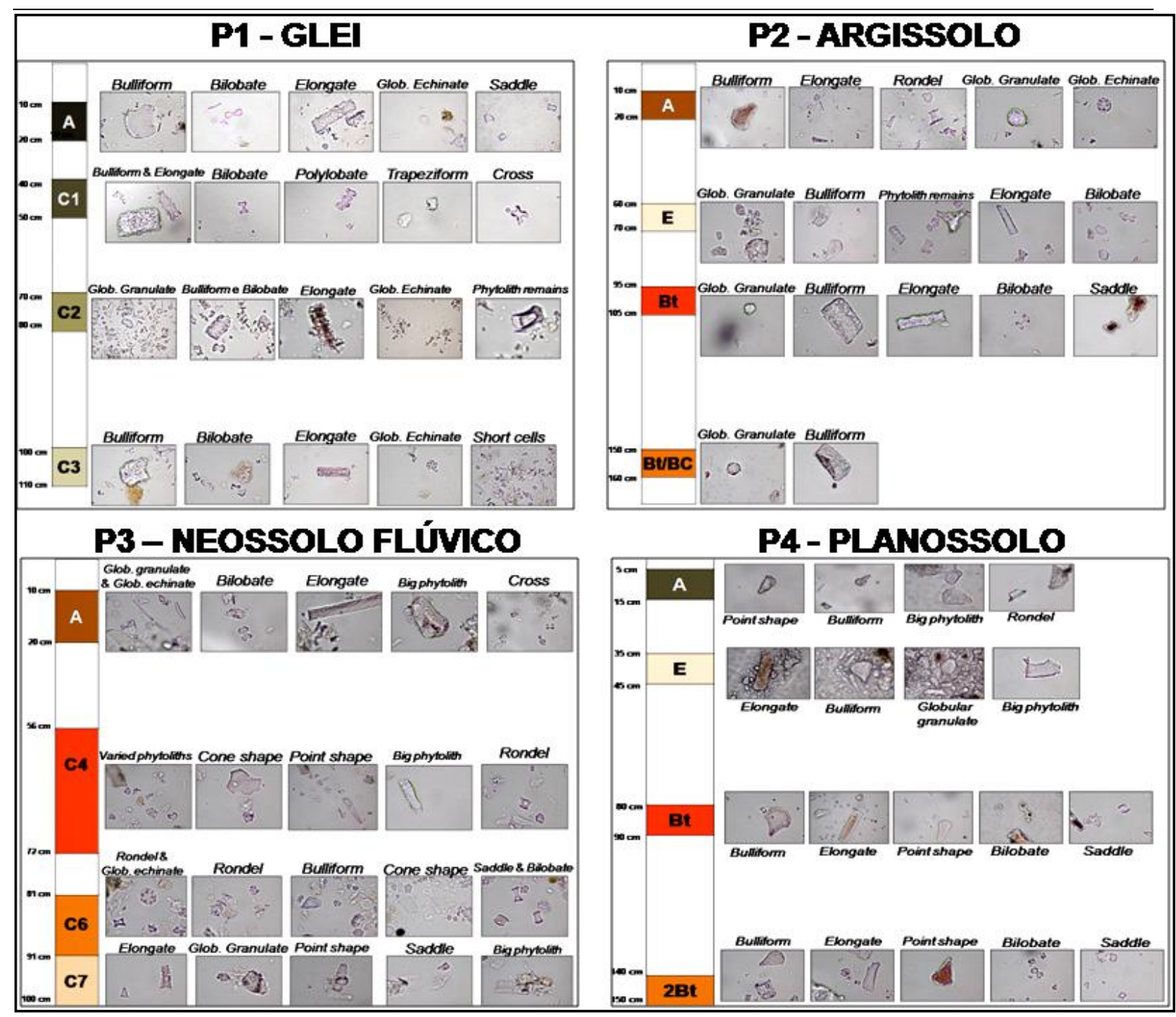

Figura 11: Principais morfotipos de fitólitos: a) P1 -Gleissolo; b) P2 -Argissolo; c) P3 - Neossolo flúvico; d) P4 Planossolo (Fotos: Coe, 2010).

As análises isotópicas das amostras de solo e das sete amostras dos principais tipos de cobertura vegetal da bacia são apresentadas na Tabela 1 e na figura 12.

O horizonte A dos perfis 1,2 e 3 apresentaram valores ${ }^{13} \mathrm{C}$ típicos de mistura de vegetação com predomínio de vegetação aberta. Corresponde à vegetação atual de todos os perfis (áreas de pasto). Os fitólitos predominantes no horizonte A dos perfis 1 e 2 são de gramíneas. No perfil 3 há o predomínio de fitólitos de espécies lenhosas, mas com presença também de gramíneas. Entre os três perfis, este é o que se apresenta menos enriquecido em ${ }^{13} \mathrm{C}$. Os perfis 1,2 e 3 se tornam mais empobrecidos em ${ }^{13} \mathrm{C}$ com a profundidade, indicando uma vegetação mais fechada, que poderia ser a original da região antes de ser transformada em pasto, como se pode observar em alguns fragmentos de mata nos topos dos morros próximos aos perfis. O perfil 4 apresenta resultados bem diferentes, com enriquecimento de ${ }^{13} \mathrm{C}$ em um horizonte mais profundo. Isto pode ser explicado pelo tipo de solo, com presença de horizonte eluvial, de onde as partículas são carreadas e um horizonte textural, onde esse material se acumula. É justamente este horizonte que se apresenta enriquecido em ${ }^{13} \mathrm{C}$, o que é confirmado pelas análises fitolíticas: os horizontes superiores quase não apresentam fitólitos enquanto que no Bt a concentração é grande e com predomínio de fitólitos de gramíneas. 
Tabela 1: Dados isotópicos $\left(\delta \%{ }^{13} \mathrm{C}\right)$ das Formações Vegetais Modernas e dos perfis de solo da Bacia do São João, RJ.

\begin{tabular}{|c|c|}
\hline AMOSTRA & VALOR ISOTOPICO \\
\hline $\begin{array}{c}\text { AM1 - Manguezal Langucularia } \\
\text { AM2 - Brejo } \\
\text { AM3 - Gramineas próximas à floresta } \\
\text { AM4 - Floresta } 2 \\
\text { AM5 - Gramineas pasto } \\
\text { AM6 - Manguezal Rizophora } \\
\text { AM7 - Floresta } 1 \text { palmeiras }\end{array}$ & $\begin{array}{l}-27,96 \\
-24,44 \\
-24,79 \\
-29,05 \\
-18,40 \\
-28,11 \\
-29,24\end{array}$ \\
\hline $\begin{array}{l}P 1 A \\
P 1 C 1 \\
P 1 C 2 \\
P 1 C 3 \\
\end{array}$ & $\begin{array}{l}-17,59 \\
-24,49 \\
-26,27 \\
-27,61\end{array}$ \\
\hline $\begin{array}{c}\text { P2 A } \\
\text { P2 E } \\
\text { P2 Bt } \\
\text { P2 Bt/BC }\end{array}$ & $\begin{array}{l}-18,73 \\
-24,26 \\
-25,18 \\
-25,89\end{array}$ \\
\hline $\begin{array}{l}\text { P3 A } \\
\text { P3 C4 } \\
\text { P3 C6 } \\
\text { P3 C7 }\end{array}$ & $\begin{array}{l}-19,86 \\
-24,98 \\
-25,05 \\
-21,16\end{array}$ \\
\hline $\begin{array}{l}\text { P4 A } \\
\text { P4 E } \\
\text { P4 E/Bt } \\
\text { P4 Bt }\end{array}$ & $\begin{array}{l}-23,72 \\
-22,81 \\
-18,81 \\
-22,13\end{array}$ \\
\hline $\begin{array}{l}\text { P5 A } \\
\text { P5 E } \\
\text { P5 Bt } \\
\text { P5 } 2 B t\end{array}$ & $\begin{array}{l}-20,65 \\
-23,83 \\
-25,72 \\
-23,73\end{array}$ \\
\hline
\end{tabular}

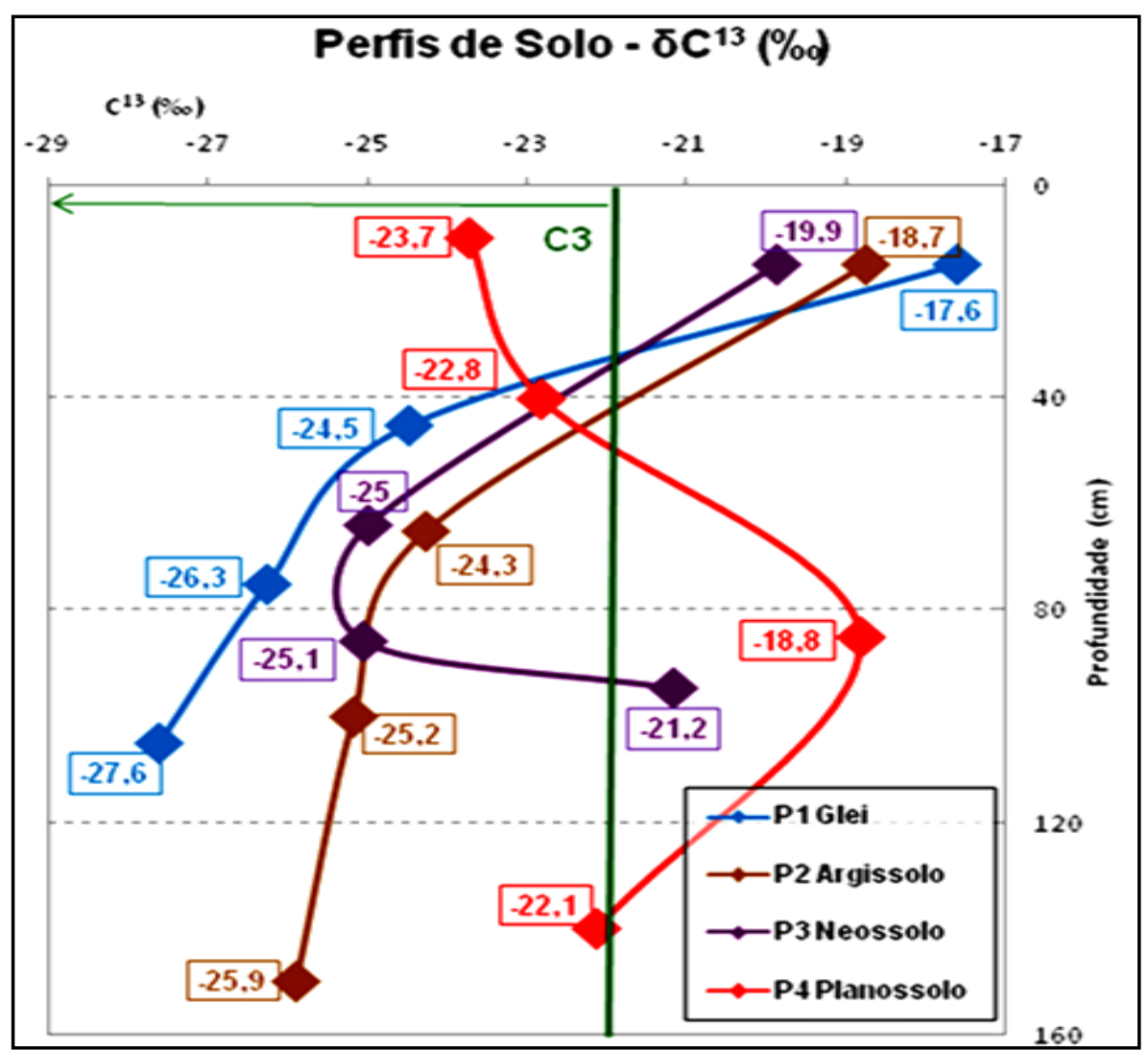

Figura 12: Dados isotópicos $\left(\delta \%{ }^{13} \mathrm{C}\right)$ dos perfis de solo da Bacia do rio São João, RJ. 


\section{CONSIDERAÇÕES FINAIS}

Os resultados apresentados contribuem para a reconstituição paleoambiental da região de Cabo Frio/Buzios, pois os fitólitos permitiram identificar, ao nível de detalhe, mudanças na densidade de cobertura arbórea. As variações observadas não indicam uma grande mudança no tipo de cobertura vegetal: a vegetação foi sempre do tipo pouco arbórea (floresta xeromórfica), sugerindo que, desde 13.000 anos cal AP, a vegetação local nunca atingiu a densidade arbórea característica de florestas úmidas. No perfil onde o índice de densidade arbórea não pôde ser utilizado por não ser estatisticamente significativo, puderam ser observadas mudanças na presença de palmeiras, numa escala de tempo "humana", não geológica, revelando outra aplicação dos estudos fitolíticos na região: relacionar os resultados com o histórico de sua ocupação e degradação.

Na Bacia do rio São João, o presente estudo trouxe resultados importantes, indicando que os fitólitos são bons indicadores de mudanças ambientais e auxiliam na compreensão da gênese de solos.

Apesar de constituírem importantes indicadores, os valores de $\delta^{13} \mathrm{C}$ não informam que espécies vegetais estavam presentes, mas as produtividades podem ser correlacionadas com a dinâmica da vegetação e o tipo de ambiente presente no local. Para se determinar o tipo de vegetação (C3 ou C4) e a época em que ela ocorreu, associam-se dados de ${ }^{13} \mathrm{C}$ com outros indicadores, como pólen e fitólitos, e com a datação por ${ }^{14} \mathrm{C}$ da MOS.

Em depósitos terrestres, as reconstruções climáticas baseadas em estudos palinológicos são muitas vezes limitadas pela destruição do pólen em ambientes secos ou oxidantes (como em solos tropicais bem drenados), ou pela variabilidade da produção e dispersão das espécies vegetais. Além disso, os valores ${ }^{13} \mathrm{C}$ da MOS registram variações entre plantas $\mathrm{C} 3$ e $\mathrm{C} 4$, mas como as plantas $\mathrm{C} 3$ incluem vários táxons além das dicotiledôneas lenhosas, os valores $\delta^{13} \mathrm{C}$ não expressam adequadamente a densidade arbórea. Já os fitólitos permitem distinguir entre gramíneas C3 e C4, podendo-se interpretar os valores $\delta^{13} \mathrm{C}$ da MOS como predominância de floresta ou pradaria $\mathrm{C} 3$.

Os exemplos apresentados ilustram a importância de estudos paleoambientais na compreensão da evolução e das mudanças ambientais de uma determinada região, bem como da necessidade de se utilizar o maior número possível de indicadores (análise multiproxy) para uma maior precisão na inferência dessas mudanças.

\section{AGRADECIMENTOS}

Os autores agradecem à Capes, pela concessão da bolsa de estágio doutoral no exterior, à FAPERJ, pelo suporte financeiro, à $\mathrm{Dr}^{\mathrm{a}}$. Guaciara dos Santos, pelas datações ${ }^{14} \mathrm{C}-\mathrm{AMS}$ e ao Dr. Marcelo Bernardes, da Universidade Federal Fluminense, e Dr. Luiz Carlos Pessenda do CENA/USP, pelas discussões esclarecedoras sobre as análises isotópicas.

\section{REFERÊNCIAS}

AB'SABER, A. N. Espaços ocupados pela expansão dos climas secos na América do Sul por ocasião dos períodos glaciais quaternários. Paleoclimas, v. 3, p. 1-19, 1977.

AB'SABER, A. N. Redutos de cactáceas, jardins da natureza, Scientific American Brasil, vol.19, dez. 2003.

ANDRADE, M. M. Paleoprodutividade costeira da região de Cabo Frio, Rio de Janeiro, ao longo dos últimos 13.000 anos cal AP. 275p. Tese de doutorado Dep. de Geoquímica, UFF, Niterói, RJ, 
2008.

ALEXANDRE, A., MEUNIER, J.D., COLIN, F., KOUD, J.M. Plant impact on the biogeochemical cycle of silicon and related weathering processes. Geochimica et Cosmochimica Acta, 61, p. 677-682, 1997.

ALEXANDRE, A., MEUNIER, J.-D., MARIOTTI, A., SOUBIES, F. Late Holocene Phytolith and Carbon-Isotope Record from a Latosol at Salitre, South-Central Brazil. Quaternary Research 51, p. 187-194, 1999.

BARBONI, D., BONNEFILlE, R., ALEXANDRE, A., MEUNIER, J.D. Phytoliths as paleoenvironmental indicators, West Side Middle Awash Valley, Ethiopia. Palaeogeography, Palaeoclimatology, Palaeoecology, 152, p. 87-100, 1999.

BARBONI, D., BREMOND, L., BONNEFILLE, R. Comparative study of modern phytolith assemblages from inter-tropical Africa. Palaeogeography, Palaeoclimatology, Palaeoecology, 246, p. 454-470, 2007.

BERRIER, A., PROSSER, J. S. Automated analysis of light-element stable isotopes by isotope ratio mass spectrometry. In T. W. Boutton \& S. I. Yamasaki (eds.) Mass spectrometry of soils. Marcel Dekker, New York, p. 1-17, 1996.

BIGARELLA, J.J., ANDRADE-LIMA, D. Paleoenvironmental changes in Brazil. In: Prance, G.T. (eds.) Biological diversification in the tropics. Columbia Univ. Press, New York, p. 27-40, 1982.

BOUTTON, T.W. Stable carbon isotopes ratios of soil organic matter and their use as indicators of vegetation and climate change. In: Boutton, T.W., Yamasaki, S.I. (eds.) Mass spectrometry of soils. Marcel Dekkerp, New York, p. 47-82, 1996.

BREMOND, L., ALEXANDRE, A., PEYRON, O., GUIOT, J. Grass water stress estimated from phytoliths in West Africa. Journal of Biogeography, 32, p. 311-327, 2005.

CAMARGO, M. N. Guia de excursão de estudos de solos no Estado do Rio de Janeiro. In: SBCS, Reunião de Classificação, Correlação e Interpretação de Aptidão Agrícola de Solos, 1979, Campinas, p.77-246.

COE, H. H. G. Fitólitos como indicadores de mudanças na vegetação xeromórfica da região de Búzios / Cabo Frio, RJ, durante o Quaternário. Tese de Doutorado, Departamento de Geologia e Geofísica Marinha, Universidade Federal Fluminense, 2009, 300p.

DESJARDINS, T., ANDREUX, F., VOLKOFF, B., CERRIC, C.C. Organic carbon and ${ }^{13} \mathrm{C}$ contents in soils and soil size-fractions, and their changes due to deforestation and pasture installation in eastern Amazonia. Geoderma, 61, p. 103-118, 1994.

DRM-RJ. Delimitação das Áreas de Preservação Permanente - APPS na Área de Atuação do Consórcio Intermunicipal Lagos São João - CILSJ. Departamento de Recursos Minerais. Rio de Janeiro, 55p., 2008.

FREDLUND, G.G., TIESZEN, L.L. Modern phytolith assemblages from the North American Great Plains. J. Biogeogr., 21, p. 321-335, 1994.

FREITAS, H. A., PESSENDA, L. C. R., ARAVENA, R., GOUVEIA, S. E. M., RIBEIRO, A. S., BOULET, R. Florestas x Savanas no passado da Amazônia. Ciência Hoje, 32, p. 40-46, 2002.

GLEIXNER, G. Molecular dynamics of organic matter in a cultivated soil. Organic Geochemistry, 3, p. 357-366, 2002. 
GOMES, J. G. Contribuição para a compreensão da gênese e evolução de solos na Bacia do Rio São João, RJ, através de análises fitolíticas. 136 p. Monografia, Departamento de Geografia, UERJ/FFP, São Gonçalo, 2012.

IBRAIMO, M. M., SCHAEFER, C. E. G. R., KER, J. C., LANI, J. L., ROLIM-NETO, F. C., ALBUQUERQUE, M. A., MIRANDA, V. J. Gênese e Micromorfologia de Solos sob Vegetação Xeromórfica (caatinga) na Região dos Lagos (RJ), R. Bras. Ciência do Solo, vol.28, p.695-712, 2004.

KILLOPS, S., KILLOPS, V. Introduction to organic geochemistry. Blackwell, Malden, MA, 2005.

LIBES, S. M. An Introduction to Marine Biogeochemistry. John Wiley \& Sons, New York, 1992.

MADELLA, M. Physiology of silica deposition. 7th International Meeting on Phytolith Research, Mar del Plata, 2008.

MARTINELLI, L. A., OMETTO, J. P. H. B., FERRAZ, E. S., VICTORIA, R. L., CAMARGO, P. B., MOREIRA, M. Z. Desvendando Questões Ambientais com Isótopos Estáveis. Oficina de Textos, São Paulo, 2009, 144 p.

MONIZ, A. C.; GRANDE, M. A.; OLIVEIRA, V. Solos do Trecho Cabo Frio-Xerém (RJ): Influência de regimes pluviais e de material de origem na pedogênese. Rev. Bras. Ciência do Solo, v. 14, p. 205214, 1990.

MOTOMURA, H., FUJII, T., SUSUKI, M. Silica deposition in relation to ageing of leaf tissues in Sasa veichii (Carriere) Rehder (Poaceae ,Bambusoideae). Annals of Botany, 93, p. 235-248, 2004.

MULHOLAND, S.C. Phytolith Shape Frequencies in North Dakota Grasses: A Comparison to General Patterns. Journal of Archaeological Science, 16, p. 489-511, 1989.

OLIVEIRA, A. C. C. Registro de paleotemperaturas na plataforma continental de Cabo Frio, Rio de Janeiro, ao longo dos últimos 13.000 anos. 205p. Tese de Doutorado Dep. de Geoquímica, Universidade Federal Fluminense, Niterói, 2008.

OSTERRIETH, M., MADELLA, M., ZURRO, D., ALVAREZ, M.F. Taphonomical aspects of silica phytoliths in the loess sediments of the Argentinean Pampas. Quaternary International, 193, p. 70-79, 2009.

PESSENDA, L. C. R., GOUVEIA, S., FREITAS, H. Isótopos do carbono. In L. Pessenda (ed.) Quaternário do Brasil. USP, São Paulo, p. 75-83, 2005.

PIPERNO, D.R. Phytoliths Analysis: an archaelogical and geological perspective. Academic Press, San Diego, 1988.

RUNGE, F. The opal phytolith inventory of soils in central Africa - quantities, shapes, classification, and spectra. Review of Palaeobotany and Palynology, 107, p. 23-53, 1999.

SCHMITT, R. S. Late amalgamation in the crustal part of West Gondwana: new chronological data and the characterization of a Cambrian collisional orogeny in the Ribeira Belt (SE Brazil), Precambrian Research, vol.133, p.29-61, 2004. 